\title{
RECONSTRUCTION OF IRANIAN CITY CENTERS AFTER THE ISLAMIC REVOLUTION (1979-2005): CASE STUDY OF MASHHAD
}

\author{
M.R. RAHNAMA \\ Department of Urban Geography, Ferdowsi University of Mashhad, Iran.
}

\begin{abstract}
Iran boasts 87,000 ha of historical places in more than 242 cities by virtue of its historical background and its geographical situation (predominantly cold and dry climate). Hence, the most critical issue the country is confronted with at present is the reconstruction of the historical buildings and places of the cities. The purpose of this study is to review the reconstruction project of Mashhad city center, Iran's second largest metropolis, as an instance of urban redevelopment projects carried out in Iran since 1979. The present study was conducted in the city center of Mashhad by dividing it into two distinct parts: direct intervention area (under supervision of governmental authorities) and indirect intervention area (under supervision of the private sector and sub-governmental authorities). The results obtained from questionnaires show that in the direct intervention area residents are faced with a great deal of problems (forced relocation, unemployment, low incomes, cultural-social alienation, eviction and so forth). In the indirect intervention area, they came up against financial problems, issuance of construction permits, etc. Finally, the city center reconstruction project has undergone a change from a large-scale redevelopment and non-participatory plan to a stockholder sharing and marketoriented commercial one. These transitional plans reveal a non-participatory approach to the city center reconstruction. For instance, property owners in the area have been ignored during this process. If this trend continues, the chances of implementing the plan in the long run would be limited.
\end{abstract}

Keywords: city center, Iran, Mashhad, reconstruction.

\section{INTRODUCTION}

In our modern world and in the age of globalization, the scientific studies of city planning are concentrated on two main tenets of re-urbanization and sub-urbanization [1]. Directing urban development is based on the prevention of urban sprawl and seeking to attain a compact city and mixed urban land use [2]. The problems may arise from the separation of the workplaces from residential areas, dividing of urban land use, and the increasing use of cars in daily transportation from workplaces to residential areas and vice versa. In addition to that, the sharp increase in fuel consumption, air pollution, length of city trips, and the alteration of agricultural land use surrounding the cities rather than using uninhabited lands in the city centers have led to the destruction of the environment and raised the importance of re-assessing urban planning policies. Therefore, development must be concentrated on re-urbanization. To cite an example, one could mention the concentration of urban development in England which is based on the below principles [3]:

1. Concentrating the majority of new developments on the inner cities.

2. Reducing the need for city trips in planning new developmental sites.

3. Re-using the previous developed areas, unused houses, etc.

On account of revitalizing city centers based on the gentrification theory in America, Wyly and Hammel (2001) have recognized three gentrification waves which began in the 1950s. The central aspect of the third wave which has initiated from the year 2000 onward is that, gentrification in this period is a part of the federal house policy and it has been made regional and has encouraged the racial and ethnic minorities and also low-income groups to participate in the gentrification process [4]. 
In spite of the benefits of development of re-urbanization and mixed urban land use, the main criticism leveled against this developmental pattern, is urban over-population. The critics believe that the density and mixed land use increase the cost of land and houses rather than leading to the reduction of environmental pollution. Consequently, the principles of the new model have been assessed by citing evidence from urban projects from countries such as The Netherlands [5].

The results obtained from evaluating the history of city center revitalization in European countries and US especially with respect to commercial revitalization shows a number of models as follows:

In Europe city center, management schemes are utilized, the most advanced of them is 'The British Town Center Management Scheme', which has had a great impact on rebuilding city centers and has helped attract investments of private/public sectors [6].

The European Union has also helped to revitalize medium-sized businesses in city centers of multitude of cities such as city centers in Portugal by means of the PROCOM plan.

'The Main Street Program' and 'The Business Improvement District' in the United States play an important role in revitalizing city centers. The aim of the Main Street Plan is the development of revitalizing strategy in order to promote economical development in the historical protected areas.

In other countries such as the Turkish metropolis of Istanbul, the reconstruction of the city center is faced with major challenges including lack of local participation, ignoring the fate of the tenants and vulnerable groups, low-income residents, and the up-down nature of plans and projects [7].

In Japan too, gentrification emerged in mid 1990s. In Japan, private gentrifiers invest in older properties in Japanese cities and small-scale redevelopment projects have been carried out by local organizations [8].

According to the estimation of Iranian Officials in the Ministry of Housing and Urban Planning, there are more than 87,000 ha of dilapidated areas in more than 242 cities of Iran [9]. One of the main objectives of the government in rebuilding old urban areas is to rebuild houses. The government has considered two million building units to rebuild in 14,000 ha of old areas, and in order to achieve this they need a credit of 14 billion dollars, the rest of which should be raised with the help of the citizens, Ministry of Housing and Urban Planning [10].

The summary above indicates the importance of paying attention to expansion of old houses, and the importance of citizen participation in the revitalization process, which is due to the limitations of financial resources.

\section{METHOD OF THE STUDY}

\subsection{Purpose}

The study aims to analyze the revitalization process of urban centers in Iran after 1979 focusing on the reconstruction of the center of Mashhad city.

The reconstruction of urban centers in Iran during 1979-2010 has had different ups and downs. It starts with the lack of program and insufficient attention to the revitalization of urban centers on the part of the government during 1979-1989 because of the outbreak of Iraq's imposed war against Iran. The process speeds up with a relatively proper attention to the revitalization of urban structures within the framework of 5-year plans (since 1989 four plans have been carried out). With the first election for city councils in 1999 and entrusting some of the state powers to city councils, the process is further accelerated. The other measures taken by state organizations and municipalities to revitalize worn-out structures of city centers include: detecting more than 87,000 ha of worn-out structures in 242 cities, providing encouragements to speed up the revitalization process such as 
exemption on construction license fees, paying $\$ 14,000$ loans for revitalizing each house and granting license for an additional storey to the local owners to increase their participation [11].

It goes without saying that in this 30-year period, the trend of activities has shifted from centralized and non-participatory activities to decentralized and participatory ones, and it is accompanied with the adoption of different patterns including large-scale to small-scale patterns for revitalization of urban centers. However, after this period, the role and position of local owners are not yet fully defined and the state and state-like institutions (organizations dependent on the government) overshadow this process. Therefore, this study aims to make a temporal analysis of the revitalization process of the city center of Mashhad and logically regulate the interference stages so that it can explain the patterns so far used for the revitalization. In the next stage, we will have an opinion survey from local residents to detect the problems and obstacles to their participation in the revitalization process. Thus, the minor objectives of the study are as follows:

1. An overall study of the background of urban revitalization and reconstruction from a worldwide perspective.

2. A study of the background of urban reconstruction in Iran especially after 1979 .

3. Reviewing the history of reconstruction in Mashhad city center especially after the Islamic Revolution (1979-2008).

4. An investigation of the problems faced by the local owners in the revitalization process of the city center and providing suggestions to speed up their participation in urban development.

\subsection{Research hypotheses}

The hypotheses of this research are formed by an analysis of the reconstruction trend in the city center of Mashhad and dividing it into two sections, namely, direct and indirect interventions, detecting the socio-economic and structural factors of the region (the small seize of the property pieces, high density of population and jobs) and the nature of the prepared detailed plans (largescale and incompatible with local conditions) and the government-centered nature of urban development regulations, which are to the interest of state or state-dependent organizations. The hypotheses follow:

1. The reason of failure of reconstruction projects in the direct intervention area of the city center is the lack of participation of local owners which is due to the fact that their interests were largely being ignored.

2. One of the factors contributing to the failure of plans is the competition of governmental departments with local owners in the reconstruction process.

3. Legal and financial problems are the chief obstacles for local residents in the reconstruction process in the indirect intervention area of the city center.

\subsection{Data collection and sampling method}

Firstly, the background of the problem in the world and in Iran was analyzed using library resources and internet. Then, considering the 1,200-year historical background of the city and the 1,200-ha area of the old structure and the location of the Complex of the Holy Shrine of Imam Reza with an area of 50 ha in its central nucleus, the Ministry of Housing and Urban Development and local institutions (municipality) directly put on top of their agenda the reconstruction of 230 ha of the old structure of the neighborhood around the Complex of the Holy Shrine of Imam Reza from 2001. 
In addition, the Ministry provided a detailed plan for the remaining section (920 ha) in which the revitalization process was indirectly carried out by municipality with the participation of the private section and local residents. So far, there has been a progress of about $10 \%$ in the direct intervention section [12]. In the indirect section, the progress rate is not known.

Therefore, in order to study the problems concerning the participation of local owners in revitalization process, the central district of the city of Mashhad was divided into two sections: direct intervention and indirect intervention.

\subsubsection{Direct intervention}

In this part of the city center, which contains about 12,000 properties and a population of about 30,000 , the revitalization operation is mainly concentrated in one sub-section. By the time of the study, about 400 properties had been purchased. The sample population contained 100 properties (25\%). Through systematic sampling method and encoding the properties and determining the distance $(c=4)$ by means of statistical formulae $(400 \div 100=4)$, the samples were selected and the required data were collected through questionnaires in the site. The data were then analyzed by means of SPSS software.

\subsubsection{Indirect intervention}

In this section of the city, due to some factors such as the vastness of the area (920 ha) and high population $(150,000)$ and unclearness of the physical progress rate of the project, we first divided the whole area into 24 neighborhoods based on structural divisions. Then, based on statistical formulae and statistical error of 0.05 and the population, 200 owner properties were selected as sample [13]. Based on the population of each neighborhood, and by means of stratified sampling method, at least four and at most 15 people were selected from each neighborhood. They were given questionnaires through which the required data were collected in the site and analyzed by means of SPSS software.

\section{PROCESS OF REVITALIZING CITY CENTERS IN IRAN}

The history of renovation of city centers of Iran shows many different patterns including urban intervention in the city center in Reza Shah era (1920-1940), high scale renovations in Mohammad Reza Shah era (1940-1979) and a mixture of renovation patterns after the Islamic Revolution (1979-2006). It is quite obvious that the renovating process of city centers has been much more developed after the Islamic Revolution in the form of master plans, rules and developmental plans, every one of which is presented considering the conditions of each period [14]. These attempts have been made in six main stages and are fully illustrated in Table 1. Such schemes range from accessibility plans to master plans. A renovation organization was founded in 1997 for development and renovation under supervision of Ministry of Housing and Planning. Despite being advantageous, this plan has mostly turned out to be uncooperative. Many of the plans have been abandoned due to the fact that in most of them the role of land owners is not clear and the top priority has been given to the improvement of physical structures and not to socio-economic standards, the most obvious example of which is provided as a brief summary of Navab plan cited below.

The plan was operationalized in Tehran, the capital city of Iran and it is a renovation plan with reasonably clear outcomes. Although, it was proposed in 1970, it was not operationalized until 1981, when the comprehensive plan of Tehran was being implemented by the municipality of Tehran. It was $6 \mathrm{~km}$ of length, covered an area of 60 ha and connected northern Tehran to its southern parts. The area had 23 old districts and a population of about 308,000 people. A range of rewarding and 
Table 1: Renovation procedures in city centers of Iran after the Islamic Revolution (1979-2005).

\begin{tabular}{|c|c|c|c|}
\hline Row & Time period & Chosen pattern & Purposes \\
\hline 1 & 1982-1985 & $\begin{array}{l}\text { Restoration- } \\
\text { accessibility }\end{array}$ & $\begin{array}{l}\text { Restoration means giving back the cultural life of } \\
\text { one section to another } \\
\text { Creating an availability and accessibility system. } \\
\text { These schemes are carried out in the national level }\end{array}$ \\
\hline 2 & 1986-1990 & $\begin{array}{l}\text { Renovation and } \\
\text { rehabilitation schemes } \\
\text { for urban zones }\end{array}$ & $\begin{array}{l}\text { Holding the responsibility of developing zones by } \\
\text { the Ministry of Housing and Urban Planning by } \\
\text { building renovation offices in urban zones } \\
\text { Creating a renovation plan for } 12 \text { cities (Dezfool, } \\
\text { Ardabeel, etc.) }\end{array}$ \\
\hline 3 & 1991-1993 & $\begin{array}{l}\text { Historical-cultural } \\
\text { zones }\end{array}$ & $\begin{array}{l}\text { Replacing systematic and complete plans with } \\
\text { un-comprehensive one } \\
\text { Announcing the zones for Isfahan, Shiraz, } \\
\text { Tabriz, Hamedan and Kerman as the main } \\
\text { cultural-historical cities } \\
\text { in the country } \\
\text { Paying attention to the mixture } \\
\text { of traditional and modern zones }\end{array}$ \\
\hline 4 & 1994-1996 & $\begin{array}{l}\text { Renovation and } \\
\text { rehabilitation or } \\
\text { large-scale } \\
\text { development plans }\end{array}$ & $\begin{array}{l}\text { The expansion of building houses in inner-city } \\
\text { areas } \\
\text { Planning for property ownership to restore, } \\
\text { integrate land plot and renovate city centers }\end{array}$ \\
\hline 5 & 1997-2000 & $\begin{array}{l}\text { Complicated urban } \\
\text { zone }\end{array}$ & $\begin{array}{l}\text { Creating a 'plan to determine suitable points for } \\
\text { housing' in } 40 \text { cities, practicing of large-schemes } \\
\text { and the lack of participation and cooperation for } \\
\text { the locals are the reasons for this plan not being } \\
\text { effective }\end{array}$ \\
\hline 6 & 2001-2006 & $\begin{array}{l}\text { Urban development } \\
\text { and renovation }\end{array}$ & $\begin{array}{l}\text { Establishing urban development and renovation } \\
\text { company under regulation of Urban Development } \\
\text { Ministry to organize city center zones and suburbs } \\
\text { in 2001, has been the biggest change in this time }\end{array}$ \\
\hline
\end{tabular}

Source: From Refs. [16, 17].

punishing strategies was used in order to encourage or pressure the owners to sell their properties, e.g. cutting off water supplies, electricity, gas, etc.

The construction of two high-rise complexes to be $180 \mathrm{~m}$ apart from each other with a high way crossing in between has the disadvantage of noise pollution due to the creation of 70-72 dB of sound which does not accord with urban standards. The purpose of authorities was not to renovate old urban areas but it was to build a highway to replace a 10-m street [15].

Evaluating the revitalization and renovation policies in the city centers of Iran proves that the schemes are designed in terms of the interests of the municipalities (articles eight and nine of property ownership). What also comes to mind is the lack of cooperation, the interference of 
governmental bodies in the destruction of city centers, their inattention to social and economic conditions of the local people, etc. Therefore, it has led to a general dissatisfaction and a continuing reluctance among people to give up their properties. The renovation scheme has thus faced a serious threat. In view of this problem, governmental specialists carrying out this plan have made an attempt to keep the owners satisfied by practicing methods such as making the residents 'the stockholders of the project' (e.g. the Majd Project in Mashhad) and therefore have been able to overcome some of the challenges [12]. Interesting to note, most of the stockholders are not even among local residents. Although the governmental and semi-governmental institutions have become aware of the importance of cooperation of private owners, they have not fully accepted it due to financial interests.

\section{THE PROCESS OF RECONSTRUCTION OF MASHHAD INNER-CITY}

Mashhad is the second largest metropolis of Iran with a population of 2.4 million people, Mashhad municipality census center [18]. It is located in the north east of Iran. The rate of the population growth in the first decade after the Islamic Revolution of Iran was the highest (8.6\% from 1976 to 1986). The literal meaning of the word 'Mashhad' is the place of martyrdom since the city is located where the eighth Imam of Shiite Muslims was poisoned and buried about 1,200 years ago. It is thus regarded as a religious city by Iranians [19]. The city receives $\sim 12$ million pilgrims and travelers annually, 270,000 of which are foreign tourists [18]. The total area of Mashhad is $300 \mathrm{~km}^{2}$, and the area of the inner-city is 1,200 ha with a population of about 200,000 people. Reconstruction projects are basically carried out in an area of 230 ha [20]. Map 1 shows the position of the inner-city and sub-areas (direct and indirect interventions) in the master plan of Mashhad.

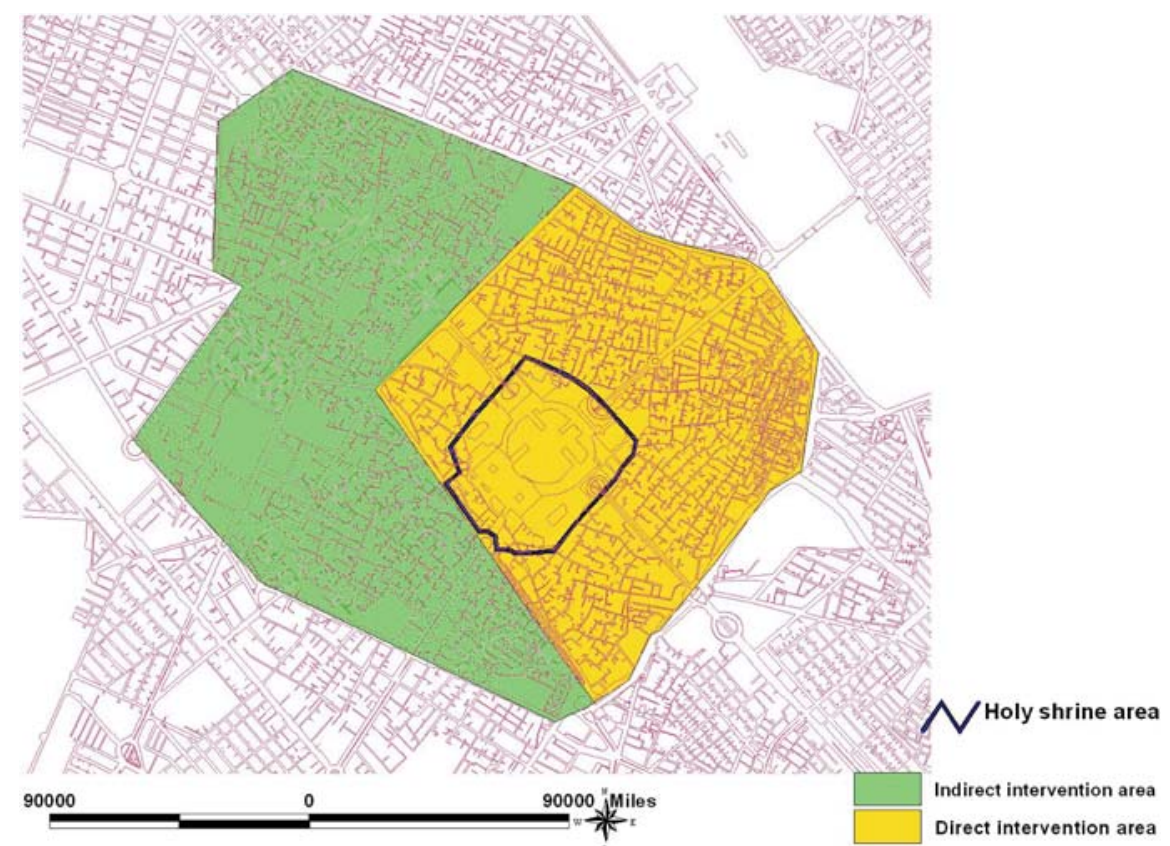

Map 1: Situation of direct and indirect interventions in the city center of Mashhad. 
The results of the socio-economic and spatial studies done in the center of Mashhad show that the average area of properties is $207 \mathrm{~m}^{2}$, and that $30 \%$ of these properties have an area of $100 \mathrm{~m}^{2}$ and less, and the average height of the building is 1.6 floors. Forty-eight percent of the properties are one-story buildings, $35 \%$ are two-story, and the rest are taller. The dominant usage of land is residential $(58.6 \%), 6.3 \%$ is commercial and the remaining has other uses. The population density in the area is 350 per ha, the employment rate is $78.8 \%$, and the unemployment rate is $21.2 \%$ in the innercity of Mashhad. The dominant mode of business in the area is retailing, while about $60 \%$ of the total commercial units are retailers.

Most of the properties in the area are private and belong to the citizens $-28.8 \%$ of the lands $1.5 \%$ belong to landlords, and the rest belong to endowment organizations such as Astan Ghods Razavi and Oghaf Endowment Office [21].

The results of these studies demonstrate that retailing and private ownership are the dominant features of the reconstruction plan. Revival of retailing must be at the center of all activities in the developmental plans. Implementation of large-scale and market-oriented commercial and reconstruction plans may harm the interests of local residents.

On the basis of the above mentioned features, and from the perspective of intervention-renewal plans, the inner-city of Mashhad is divided into two areas as follows:

1. The central city core (near 280 ha) including Holy Shrine of Imam Reza (50 ha) and the area around it (230 ha). This area is in the direct intervention area of the city center.

2. The remaining area around the central city core or inner-city, which is nearly 900 ha. This area is under the supervision of municipality and its indirect intervention. Map 1 illustrates the situation of these two areas.

\section{THE INTERVENTION IN THE CENTRAL TEXTURE OF THE CITY MAY BE DIVIDED INTO TWO PERIODS}

\subsection{Before the Islamic Revolution (1979)}

This period is itself subdivided into two periods as follows:

5.1.1 The period of first Pahlavi (Reza Shah, 1920-1940)

Map 2 displays the first intervention in the city center of Mashhad. Construction of new streets and squares in the historical texture was the key attribute of this period.

5.1.2 The period of second Pahlavi (Mohammad Reza Shah, 1940-1979)

Map 3 shows the second intervention. The major intervention around the Holy Shrine came about in this period, especially the area around the Holy Shrine underwent a lot of changes, although the historic texture was kept.

\subsection{After the Islamic Revolution (1979-2005)}

The interventions in the central texture of Mashhad after the revolution include two major plans as cited below:

5.2.1 Development plan of the Holy Shrine (1981-2001)

It took 20 years for the plan of the Holy Shrine of Imam Reza to be completed, that is, from 1981 to 2001 which was operationalized by Astan Ghods Razavi (Map 4). The area of this plan increased 


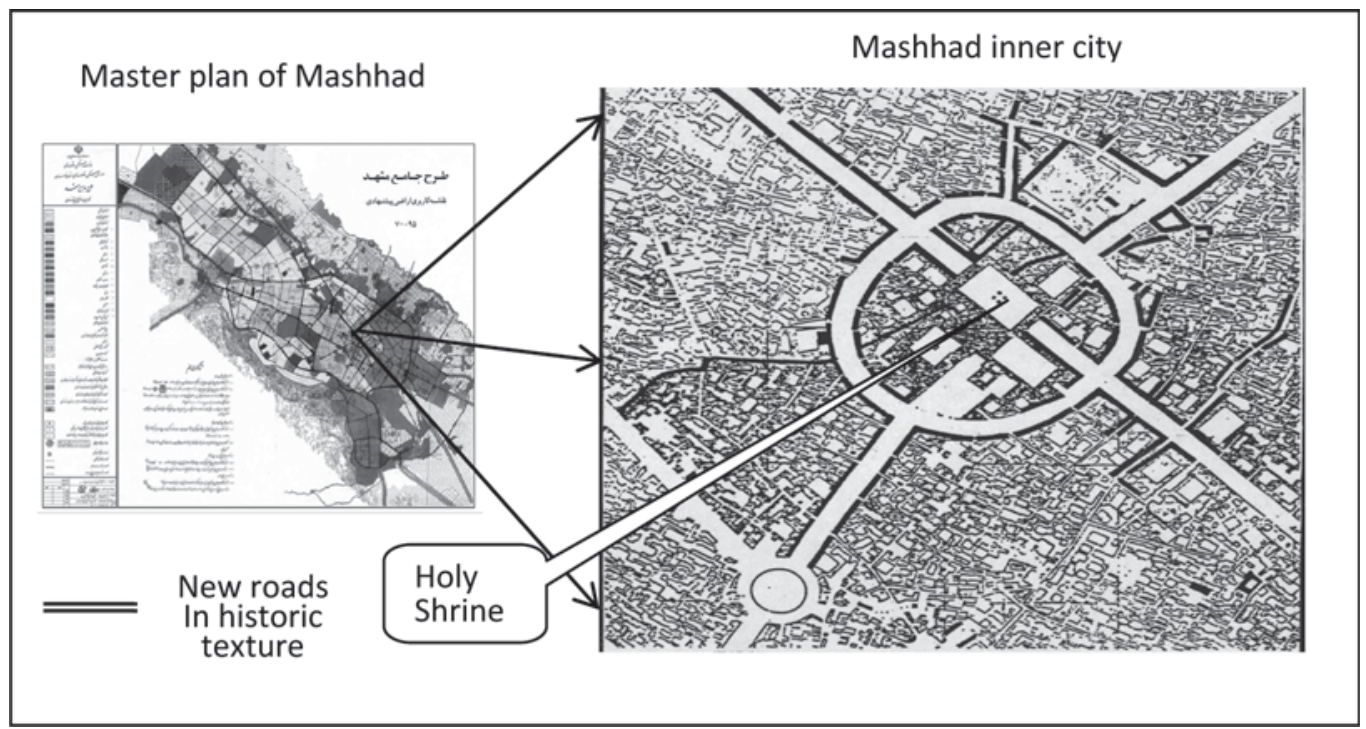

Map 2: Location of the inner-city and the first intervention in the city center of Mashhad.

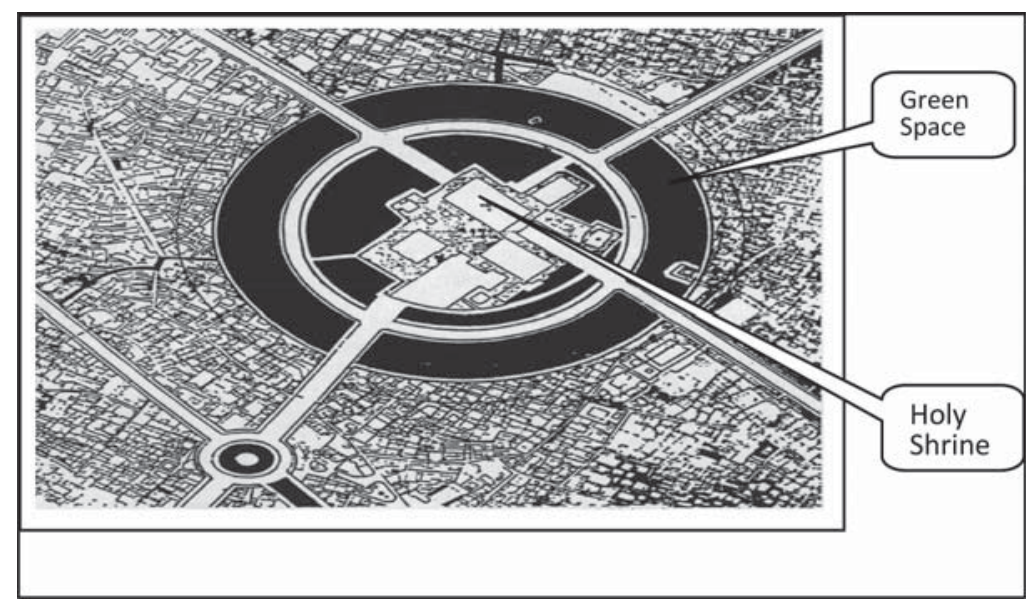

Map 3: Second intervention in city center of Mashhad in 1975. Source: From Ref. [21].

from 12 to 50 ha after the revolution. About 2,500 plots of land were bought from the owners residing in the area [22]. Moreover, some of the businesses that were formerly concentrated around the Shrine were destroyed in the second Pahlavi period, the purpose of which was to extend the Holy Shrine. The important consequence of this plan was the destruction of the greenery surrounding the Holy Shrine (Map 4). 


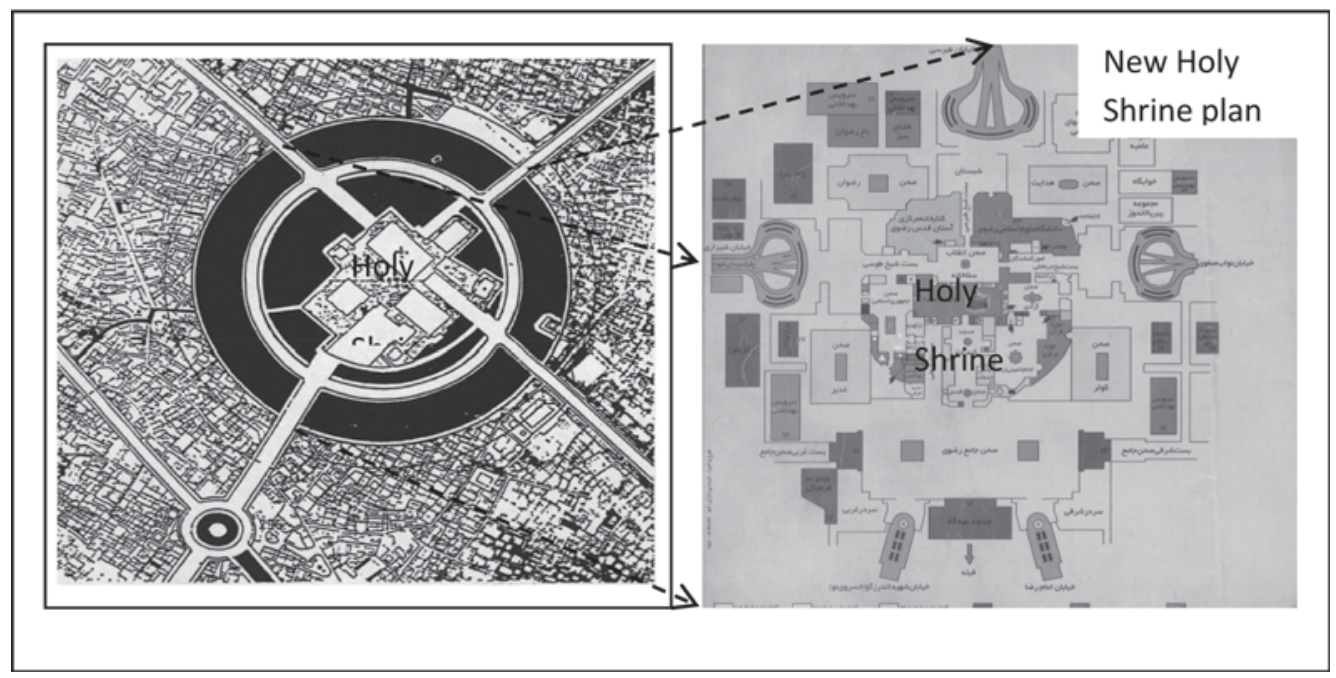

Map 4: The Holy Shrine development plan. Source: From Ref. [22].

\subsubsection{The plan of reconstruction of the city center of Mashhad from 1991 to 2004}

It was carried out in an area of 230 ha which surrounded the area belonging to the first plan; however, it has changed four times as follows:

1. The large-scale construction plan (Maps 5 and 6).

It was the first of the plans after the Islamic Revolution which aimed at reconstruction of the city center of Mashhad. In order to implement this plan, a new governmental organization entitled 'Maskansazan' was founded. Three large-organizations played a role in the foundation of it, namely, Astan Ghods Razavi, Urban planning and Housing ministry, and Mashhad Municipality. The plan was of a large-scale, designed to be implemented in an area of over $700 \mathrm{~m}^{2}$, but it was also an ambiguous one. The plan did not receive a warm welcome among the residents, and there were serious clashes between the people and the authorities due to which the plan underwent changes.

2. Changing the large-scale construction plan to the reconstruction plan of 1988-2002 (Map 7)

Due to the vagueness and the market-oriented nature of the construction plan of the city center of Mashhad and its non-participatory approach, it was not implemented at the time. Therefore, the authorities changed the plan and its standards this coincided with the first Iranian City Council elections which led to the formation of Mashhad City Council in 1988. The pressure of the owners on one hand, and the vagueness of the plan on the other, brought about a major change in its content, which finally resulted in introducing the reconstruction plan. The main advantage of this new plan was that it was more flexible, and its design was realistic. Thus, the average area of the properties was reduced from $700 \mathrm{~m}^{2}$ to a minimum of $250 \mathrm{~m}^{2}$. A number of main streets were also removed as a result of the implementation of this plan [23]. Changing detailed plan regulation was the most important event that took place. Map 7 shows the reconstruction plan of the city center of Mashhad.

3. Market-oriented commercial projects (from 2002 onward)

Another urban plan that was designed for the direct intervention area of the historical city of Mashhad is the large- and medium-sized market-oriented projects. These projects were designed by 


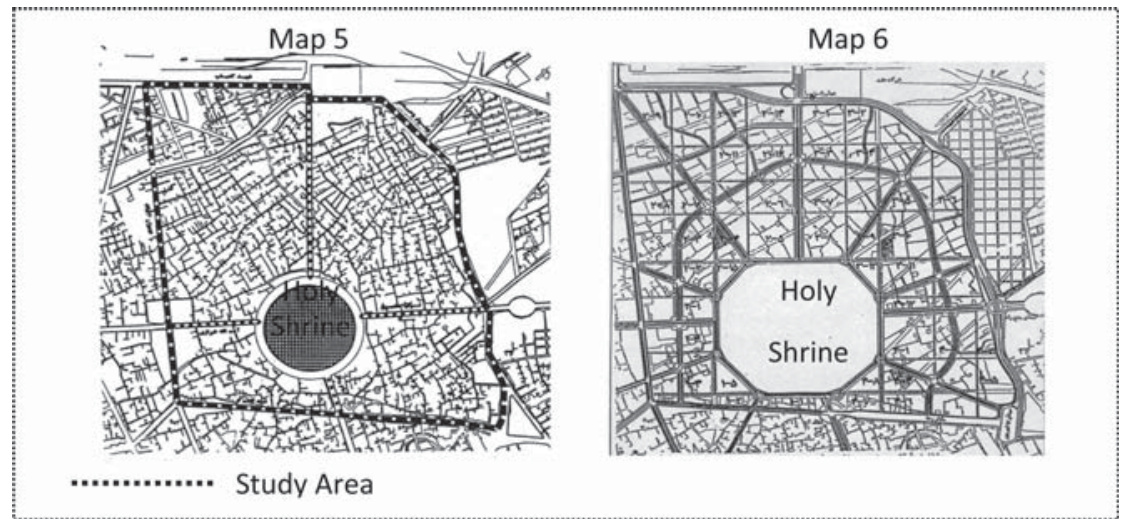

Map 5: Study area of Mashhad city center reconstruction plan in 1991. Source: From Ref. [21]. Map 6: Proposal for Mashhad city center reconstruction plan in 1991. Source: From Ref. [21].

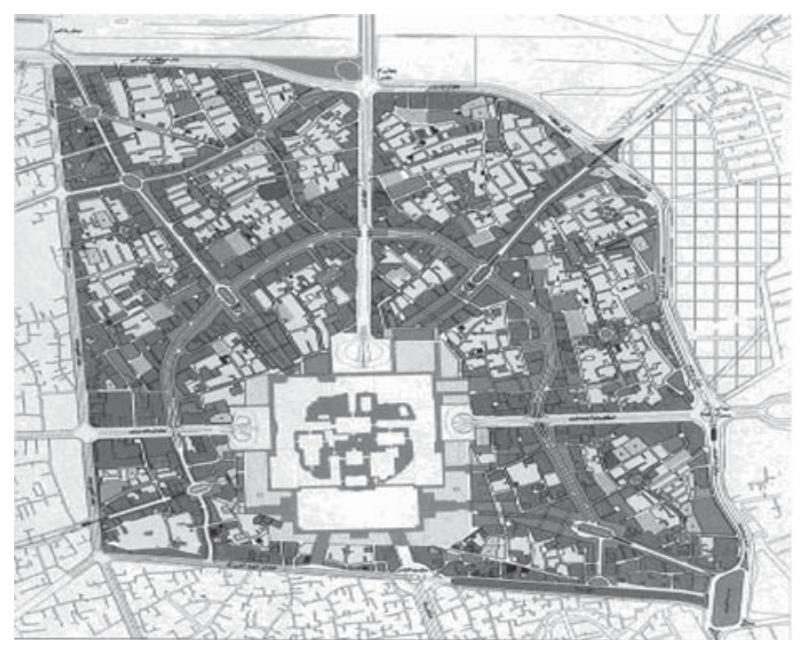

Map 7: Mashhad city center reconstruction plan (1998).

the Municipality of Mashhad and were carried out in collaboration with the private sector (large construction companies). Local owners did not take part in it due to the fact that they did not have big plots of land. Therefore, the local residents were made to sell their properties to the municipality. If they refused to do so, they were subjected to Act 9 of the municipality law which stipulated the confiscation of the properties that were located within the urban development plan. One of the most important measures taken by the municipality in this regard is the widening of Nadery Street. Map 8 pictures the situation of these eco-commercial projects in the area. What the municipality did was to develop 15 commercial complexes along Nadery Street. The average land area of each complex is $2,193 \mathrm{~m}^{2}$, the total floor space is $10,383 \mathrm{~m}^{2}$, and the average height is seven floors. About $50 \%$ of the total land use is commercial [24]. The characteristics of these projects are being inflexible and non-participatory as well as causing environmental pollution. 


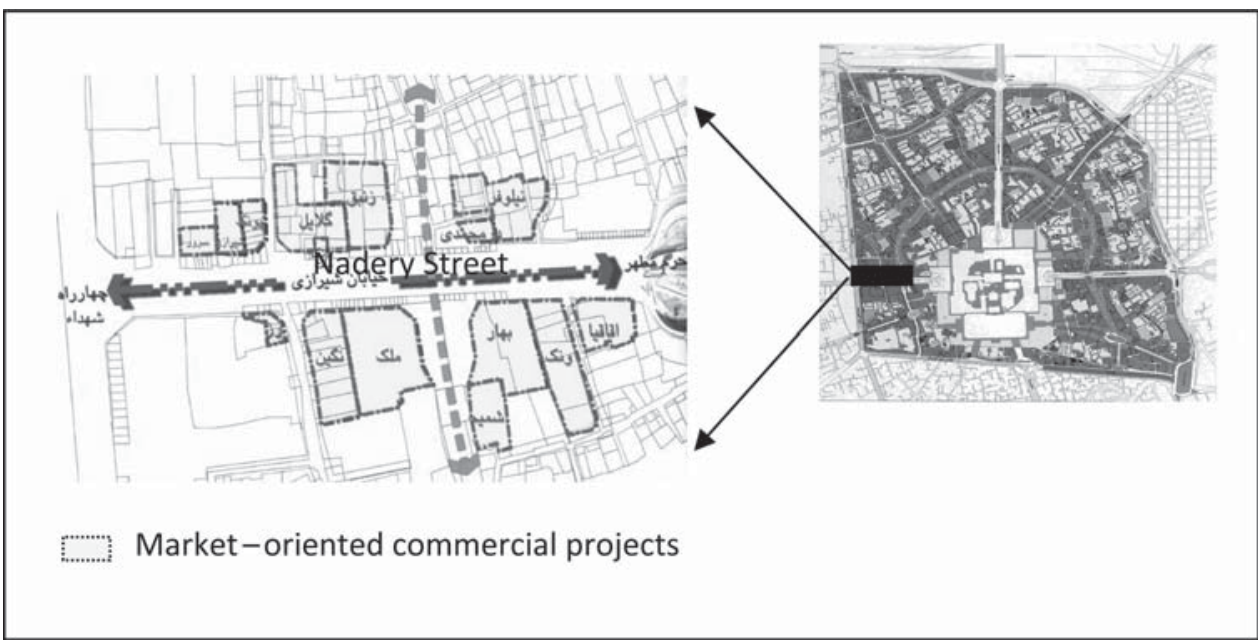

Map 8: Market-oriented commercial projects around Nadery Street in the city center of Mashhad Source: From Ref. [19].

4. The stockholder sharing project (from 2005 onward).

The latest urban plan designed for the direct intervention area of the city center of Mashhad is the Stockholder sharing project. This project was operationalized by a governmental corporation which has $15,100 \mathrm{~m}^{2}, 615$ commercial units, 277 residential units, $84,000 \mathrm{~m}^{2}$ of floor area, and 12 flats. This project is the biggest to be implemented in the distance of $300 \mathrm{~m}$ from the Holy Shrine in the city center of Mashhad. One of the differences between this project and the others is the increased participation of the owners and the citizens as stockholders of the project. It is divided into 14 million public stocks. The participation of the owners was about $20 \%$ and the total cost of the project was estimated to be around $\$ 55$ million [25]. Although this project is not a participatory one especially for local residents and owners, it is the first to consider the owner rights.

\section{THE RESULTS OF ANALYSISNG THE QUESTIONNAIRES}

The results of analyzing the questionnaires in the two separate sections of direct and indirect interventions are as follows:

\subsection{Direct intervention area}

The descriptive results of the analysis of 100 questionnaires filled by the owners concerning the effects of the implementation of the reconstruction project are as follows. The average age of the respondents was 54.5 years and the literacy rate was $76.7 \%$. Moreover, $83 \%$ of the respondents had been born within the neighborhood, $10 \%$ in the city and the rest outside the city. This indicates that most of the residents are natives. About $56.7 \%$ of the properties had been procured from the owners through obligatory possession and exercising legal force. This indicates that the project is non-participatory.

The results of analyzing the questionnaires in this section are indicative of compulsory selling of the properties to state or state-dependent organizations. Thus, the research hypotheses are verified 
proving that the plan is non-participatory and that state organizations compete with the owners and apply legal force in order to dispossess the owners.

The socio-economic and structural results obtained from questionnaires regarding the effect of the renovation plan on residents (including 100 property owners) reveals the fact that in the direct intervention part of city center of Mashhad, $73.3 \%$ of the owners have been made to leave their home and move to other parts of the city, and the average distance between workplace and home has increased from $766 \mathrm{~m}$ (before the plan) to $3,157 \mathrm{~m}$ (after evacuation). In addition to that, about $60 \%$ of the workplaces of landowners used to be in this area which reduced to about $23.3 \%$ after the implementation of the renovation plan. Only $3.3 \%$ of the owners' workplaces was near their house after the implementation process, in comparison with $26.7 \%$ before. The proportion of nongovernmental jobs had also reduced from $73.3 \%$ to $46.7 \%$. It is worth mentioning that $26.7 \%$ of the proprietors had a change of job after the plan was conducted. The results demonstrate that $67.7 \%$ of the proprietors had indicated a $50 \%$ difference between real price of properties and selling price to the sub-governmental authorities. On the whole, $96.7 \%$ of the owners were not satisfied with the plan and stated that it had a negative effect on their lives. Buying fairly at current prices and sharing profits with proprietors are among suggestions made by them in order to facilitate the developmental process. Therefore, one can conclude that this plan has only managed to impoverish the initial owners.

\subsection{The process of urban reconstruction in the indirect intervention area}

In addition to the direct intervention operations of governmental and sub-governmental authorities in the city center of Mashhad, as it was mentioned above, many groups including residents and developers also carried out housing and commercial construction projects in the inner-city of Mashhad. The municipality of Mashhad has issued construction permits for the owners on the basis of regulations of detailed plans. Due to the profits involved, developers outside the area also took part in the urban reconstruction process [26]. Upon consideration of the results obtained from questionnaires, the problems related to housing and urban reconstruction may be classified as follows:

1. Problems of obtaining loans from banks: many banks were reluctant to take part in the housing reconstruction project due to high risks involved in the payment of installments. This problem was mentioned by $65 \%$ of the residents.

2. Issuance of construction permits by the municipality was a time consuming process, about $37 \%$ of the residents complained of its inconvenience.

3. Problems regarding the transport of construction materials. This was stated by $44 \%$ of the residents.

4. Financial problems which was voiced by $44 \%$ of the residents.

5. Pressure of family members. Family members, especially the youth, insist on leaving old neighborhoods in the city center.

6. Legal problems of inheritance. This was mentioned by $9.54 \%$ of the respondents. The results of this field work show that $43 \%$ of the residents have renovated their homes while the remaining $57 \%$ have not taken any actions in this respect.

The owners in this section enjoy more freedom for property and house reconstruction in comparison with the direct intervention section. That they are not forced to sell their properties to state-dependent institutions; the regulations of the detailed plan are rather flexible, and state institutions are not rivals for the private section. However, reconstruction in this section does not show much progress because 
of the legal problems (in issuing construction permits), financial problems (banks do not give loans) and the financial weakness of the owners.

Evaluating the policies of renovation and revitalization of city centers of Iran indicate that the government and its organizations play a major role in the city center renovation while the cooperation of local owners in the urban developmental process is very insignificant.

\section{CONCLUDING STATEMENTS}

The results of this research show that the periods of urban reconstruction after the revolution are characterized by five distinct stages as follows:

1. First stage (1980-1987): Apart from the Holly Shrine Plan, there was no clear and comprehensive plan for city reconstruction. All Iranian cities had to come up against mass rural migration to cities. The rate of population growth in Mashhad in this period was 8\% per year (the highest rate in Iran).

2. Second stage (1988-1998): This period involved the transition from land supply to housing supply. The first mass redevelopment plan of Mashhad city center was presented in 1991. The main purpose was to replace the old texture of the city with new buildings.

3. Third stage (1998-2002): There was a change from the mass redevelopment plan to the reconstruction plan in this period. This change was triggered by the two following elements:

The resistance shown by residents against the redevelopment plan in the city center.

The formation of city councils in all Iranian cities since 1998 and the pressure of local residents on councilors to protect their ownership rights.

4. Forth stage (2002-2005): This is the period of market-oriented commercial projects in the historic city center of Mashhad. Sub-governmental organizations took over the properties of the residents and built new constructions by means of new detailed construction plans and the supporting rules and regulations.

5. Fifth Stage (2005-2008): This is the stage of Stockholder sharing projects. This less participatory renovation plan began in 2005 which is of two parts: the civilian part (the owners and developers) and the government and municipality part. Since this plan has been recently designed, its evaluation needs more time. The city center of Mashhad is the geographic, socio-economic and cultural as well as religious area of the city. The core is religious due to the existence of the Holy Shrine and authorities share a sensitive mind on it; since it attracts more than 10 million pilgrims a year. Hence, they have divided the inner-city of Mashhad into two sections of direct intervention (which surrounds the Holy Shrine) and indirect section which goes beyond it.

The main purpose of the authorities in the direct intervention area was to respond to the needs of pilgrims and tourists. As a result, they have designed large-scale renovation plans that would impede the participation of local owners. There is no correspondence between renovation plans and capability of local owners.

As the reconstruction plan of the center of Istanbul failed due to lack of local participation and a concentrated up-down planning system [7]. The reconstruction plan of the center of Mashhad, which was expected to be completed in 15 years (1991-2006), has had only a 10\% progresses and is estimated to be completed in the next 90 years [12]. Encouraging local participation, flexibility of the plan and lack of interference on the part of the government are the secrets of the success of the plan in this section of the city. 
In the indirect intervention area of Mashhad, many elements including the owners, developers, officials and sub-governmental authorities were in effect in renovation process. The problems of owners in the renovation of their property were mostly banking loans, regulatory administrations, the nature of the plan which was non-participatory, financial matters and so forth.

Accelerating the renovation process in the city center of Mashhad needs to be done through the assignment of power to local communities in order to take the decision-making process into their own hands [27]; moreover, sub-governmental organizations should support property owners and not challenge them. This need was found in all stages of the renovation process. In addition, a communicative planning process is highly needed so that the owners and stockholders consider themselves to be in a win-win relationship with the government [3].

The final results of the city center reconstruction process in the city center of Mashhad show that the governmental organizations should function as the private sector. In addition to that, it demonstrated the poor participation of local owners and signaled the destruction of cultural and historical monuments. Therefore, two approaches to the inner-city reconstruction are proposed as follows:

1. Local owners must be assisted by new legislations in order to reconstruct their properties themselves. Urban infra-structure must be provided by the government and the loan making processes by banks should be facilitated [28].

2. Large-scale market-oriented projects should be replaced with small and medium-sized ones, owing to the fact that the sizes of land plots are small. Therefore, the authorities should support local owners in order to reconstruct their properties.

Moreover, other results of the study of Mashhad city center indicate the separation and disintegration of the totality of the city center, preparation of inharmonious development plans, diverse laws and regulations, and numerous decision-making institutions in the management scope of the development of urban centers. These conditions together with plans inflexible to local conditions and the competition of state-dependent institutions with local residents have slowed down and mystified the reconstruction trend of urban centers in Iran.

Considering the existence of more than 87,000 ha of worn-out urban structures in more than 242 cities and the weakness of state resources, and the experience of the failure of the plans executed by municipalities in other cities (the execution of Navab Project by Tehran Municipality in 1981 with a length of $6 \mathrm{~km}$ in the city center of Tehran) [15] indicates the necessity of local participation and the application of flexible patterns and a unified urban management. Finally, all of activities that have done by government authorities in the direct intervention of Mashhad city center indicate a socio-economic filtering of local residence by middle and upper classes, which means that the government has worked in the interest of capital gain, not the social majority [29].

\section{ACKNOWLEDGMENTS}

I hereby wish to express my special thanks to Dr. Rajabali Askarzadeh, Dept. of English, Ferdowsi University of Mashhad, for reading the whole article, and then to the editors (unknown reviewers) of my article for their informative suggestions.

\section{REFERENCES}

[1] Hellemman, G. \& Wassenberg, F., The renewal of what was tomorrow's idealistic city, Amsterdam's Bijlmeree. Cities, 21(1), pp. 3-17, 2004.

[2] Burkhart, J., Reviews of Environmental Health, Environmental Health Perspectives: 112(9), p. 934, 2004. doi:10.1289/ehp.04112943 
[3] Stead, D. \& Hoppenbrouwer, E., Promoting an urban renaissance in England and the Netherlands. Cities, 21(2), pp. 120-130, 2004. doi:10.1016/j.cities.2004.01.005

[4] Bound, M. \& Morris, A., Second wave gentrification in inner-city Sydney. Cities, 23(2), pp. 99-108, 2006. doi:10.1016/j.cities.2005.09.001

[5] Helleman, G. \& Wassenberg, F., The renewal of what was tomorrow's idealistic city, Amesterdam's Bijlmermeer high-rise. Cities, 21(10), pp. 3-17, 2004. doi:10.1016/j.cities.2003.10.011

[6] Lopes Balsas Carlos, J., City centre revitalization in Portugal. Cities, 17(1), pp. 19-31, 2000.

[7] Karaman, O., Urban pulse-(re)making space for globalization in Istanbul. Urban Geography, 29(6), pp. 518-523, 2008. doi:10.2747/0272-3638.29.6.518

[8] Buther, T., For gentrification. Environmental and Planning, 39(1), pp. 162-181, 2007. doi:10.1068/a38472

[9] Econews, http://www.econews.ir/main1.asp?a_id=6907, 2008.

[10] Ministry of Housing and Urban Planning, http://www.udro.org.ir/en/index.asp, 2007.

[11] Aeini, http://www.udro.org.ir/fa/content/view/760/123/, 2008.

[12] Gabarzadeh, M. \& Tabatabaei, M.H., Methods of the owners participation in Mashhad city centre development projects, Mashhad Municipality Report, pp. 13-15, 2005.

[13] Hafeznia, M.R., An Introduction to the Research Method in Humanities, Samt Press: Tehran, Iran, pp. 136-140, 2004.

[14] Gamal, M.G., Massive Old Texture of City Centre Renovation, http://www.udro.org.ir/news/ fullstory.asp?n=2554, 2007.

[15] Kamrava, M.A., Introduction to Modern Urbanization in Iran, Tehran University Publications: Tehran, pp. 180-188, 2005.

[16] Kalantari, H. \& Pourahman, A., Techniques and Experiences in Renovation Planning of Historical Area of Cities, Humanities Research Centre: Tehran, pp. 33-35, 2005.

[17] Rahnama, M.R., Planning for the Central City Zones (Theories, Techniques and Experiences), Ferdowsi University Press: Mashhad, pp. 305-306, 2009.

[18] Mashhad Municipality Census Centre Transportation and Traffic Office, Mashhad Population Report, 1, pp. 9-10, 2005.

[19] Imam, S.K., Mashhad, Buzargomahry Ltd: Mahhad, Iran, pp. 34-36, 1948.

[20] Ministry of Housing and Urban Planning, Mahhad Inner City Master Plan, pp. 122-125, 1984.

[21] Tash Consultant Engineers, Brief Report on Mashhad City Centre Revitalization Studies, pp. 45-60, 1984.

[22] Dayside, Development plan of holly shrine report, Haram Journal, 1(31), p. 67, 1993.

[23] Mona, E., Review on experiences intervention city center of Mashhad. Haft Shahre Journal, 13(2), p. 8, 2001.

[24] Tash Consultant Engineers, Mashhad City Centre Revitalization Reports, 1, pp. 123-124, 1987.

[25] Noroze, A., Stockholder sharing project in city centre of Mashhad. Khorassan Newspaper, 16924, pp. 11, 2008.

[26] Rahnama, M.R., Process of Mashhad city centre renewal. Geography and Regional Development Journal, 1(3), pp. 145-147, 2005.

[27] Arnstein, S.R., A ladder of citizen participation. JAIP, 4(35), pp. 216-224, 1969.

[28] Mike, G., Urban governance and vulnerability: exploring the tensions in Sydney's response to bushfire threat. Cities, 22(1), pp. 55-64, 2005.

[29] Mends, L., Neil smith's contribution to urban studies on gentrification (1979-2009). Multilayerd Cities and Urban Systems, ed. G.R. Anant, Hyderabad Metropolitan Development Authority and Osmania University with IGU Urban Geography Commission: India, 2009. 